УДК $327(460+410)$ «1918/1931»

DOI: 10.26693/ahpsxxi2019.01.001

\title{
РОЗВИТОК ІСПАНСЬКО-БРИТАНСЬКИХ ВІДНОСИН ПІСЛЯ ПЕРШОЇ СВІТОВОЇ ВІЙНИ (НА ШПАЛЬТАХ ІСПАНСЬКИХ І РАДЯНСЬКИХ ГАЗЕТ)
}

\author{
Анастасія Хмель, \\ e-mail: hmelnastia@ukr.net \\ ORCID: https://orcid.org/oooo-OoO2-4881-7859 \\ Чорноморсъкий національний університет імені Петра Могили, \\ Украӥна, 540о3, м. Миколаӥв, вул. 68 Десантників, 10 \\ Лідія Біліченко, \\ e-mail: bilichenko.lidia@gmail.com \\ ORCID: https://orcid.org/oooo-ooo1-5547-9248 \\ Чорноморсъкий національний університет імені Петра Могили, \\ Украӥна, 540о3, м. Миколаїв, вул. 68 Десантників, 10
}

Питання розвитку іспано-британських відносин після Першої світової війни досить побіжно досліджувалося як зарубіжними так і вітчизняними науковцями. Тому навіть на сучасному етапі у працях дослідників побутує така думка, що у міжвоєнний період відносини між двома краӥнами майже не розвивалися. 3 огляду на це, автори поставили собі за мету на основі іспанських та радянських періодичних видань того періоду, які були одним з важливих джерел інформацї, проаналізувати іспано-британські відносини після Першої світової війни. У ході дослідження було встановлено, що протягом 20-3о-х рр. відносини між Іспанією та Великою Британією були більше розвиненими у економічній сфері, але складними та суперечливими у політичному напрямку.

Ключові слова: Іспанія, Велика Британія, Радянсъких Союз, відносини, Периа світова війна, преса

Постановка проблеми. Здійснюючи аналіз іспансько-британських відносин після Першої світової війни, звертаємо увагу на позиції цих країн під час війни, адже вони вплинули на похолодання відносин у перші повоєнні роки. Так, нейтралітет, який обрала Іспанія, був важливим рішенням не тільки для неї, але й для країн Антанти. Це вплинуло як на зовнішню, так і на внутрішню політику країни. Щодо ситуації всередині Іспанії (їі національної політики), нейтральна позиція сприяла економічному піднесенню завдяки міжнародній торгівлі та транспортним послугам країнам Антанти. Однак, це не підштовхнуло Іспанію до економічної модернізації і не вирішило її соціально-економічних проблем, що стало чинником нестабільної ситуації всередині країни у повоєнні роки.

Які ж були наслідки нейтралітету у зовнішньополітичній площині? Відмовившись від участі у війні, король Іспанії Альфонсо XIII поступився ідеєю отримати Португалію та Гібралтар. 3 іншого боку, наслідки нейтралітету виявилися в нереалізованих цілях, у досить пасивному становищі зовнішньої політики Іспанії, а також ії другорядній ролі в Європі в повоєнні роки. Одним з небагатьох досягнень нейтралітету Іспанії у війні виявився статус країни-засновниці Ліги Націй (але поки що інформації щодо відносин Іспанії та Великої Британії в багатосторонньому форматі в Лізі Націй протягом досліджуваного періоду на сторінках іспанських чи радянських газет не виявлено). 
Тому, неординарною й важливою є проблема збігу або розбіжності інтересів на міжнародній арені між Великою Британією, однією з країн-переможців у війні, і нейтральною країною, тобто Іспанією. Цілком природно, що в той час проблема Гібралтару була каменем спотикання у відносинах між двома країнами, хоча це мало висвітлювалась пресою. Так само одним 3 найбільш важливих складових зовнішньої політики обох держав була економічна складова, що чітко проілюструвала преса. Існували також інші проблеми у відносинах між двома країнами, про які йдеться нижче.

У той час же на відносини між Іспанією та Британією зазначеного періоду позитивно впливали кровні монарші зв'язки між іспанським і британським монархами. Так, король Іспанії Альфонсо XIII був одружений на принцесі Вікторії Евгенії Батенберг, яка була онукою королеви Великої Британії Вікторії та доводилася двоюрідною сестрою діючому британському монарху Георгу V 1 .

Пильно за іспансько-британськими відносинами стежив й Радянський Союз. Хоча й дипломатичні відносини між Іспанією та Радянським Союзом були встановлені лише в 1933 р., а обмін посольствами відбувся аж у 1936 р. (напередодні Громадянської війни в Іспанії) - це не заважало двом країнам співпрацювати та цікавитися зовнішньою політикою одна одної. Так, протягом 1918-1929 рр. Мадридом було видано шість віз радянським громадянам ${ }^{2} .3$ іншого боку, така зацікавленість Радянським Союзом іспансько-британськими відносинами, була викликана напруженими відносинами між самим Радянським Союзом та Великою Британією. Зокрема, в 1923 р. уряд Великої Британії видав «Ультиматум Керзона» - ноту радянському керівництву, в якій СССР звинувачувався в антибританській політиці на Сходіз, а в 1927 р. взагалі британсько-радянські дипломатичні відносини були розірвані4.

Отож, відносини між Іспанією і Великою Британією будувались як у рамках двостороннього формату, так і в багатосторонньому форматі, зокрема у напрямку Марокко, в який також тісно впліталися інтереси Франції, й, меншою мірою, Італії та Німеччини.

Викладення основного матеріалу. Для проведення цього дослідження були використані матеріали як іспанських, так і радянських періодичних видань. Зокрема, це архів іспанської газети «La Vanguardia», яка була заснована 1 лютого 1881 року5 як орган преси Ліберальної партії. Вона була першою іспанською газетою з кореспондентами в Парижі та Берліні. Окрім, «La Vanguardia» слід відзначити «Reuter»одне 3 найбільших у світі міжнародних агентств новин і фінансової інформації, яке існує з середини XIX століття, адже частину новин «La Vanguardia» запозичувала саме з цього новосного порталу (що зазначено зазначено у відповідних посиланнях). Серед радянських газет, які висвітлювали питання іспансько-британських відносин, слід зазначити «Вечернее радио», «Пролетарская правда», «Харьковский пролетарий», «Луганская правда», «Красное знамя», «Коммунист», «Красный черномоpeu»».

Виходячи з вищесказаного, автори ставлять собі за мету дослідити та проаналізувати на основі іспанської та радянської преси 1918-1931-х рр. іспано-британські відносини після Першої світової війни.

\footnotetext{
${ }^{1}$ Serrano, C.S. (2018). Alfonso XIII. Real Academia de la Historia. Retrieved from http://dbe.rah.es/biografias/6415/alfonso-xiii

2 Волосюк, О.В., Медников, И.Ю. \& Пожарская, С.П. (2013). История внешней политики Испании. Москва: Международные отношения, 215.

3 Сергеев, Е.Ю. (2015). Ультиматум Керзона Советской России 1923 г.: новая интерпретация. Вестник РГГУ. Серия: Политология. История. Международные отношения, 11 (154), 97.

4 Худолей, К.К. (2017). Эволюция идеи мировой революции в политике Советского Союза (эпоха Коминтерна и социализма в одной стране). Вестник СПбГУ. Политология. Международные отношения, 10 (2), 155.

5 La Vanguardia (1881, 1 de febrero), p. 4.
} 
Як помічаємо, перші повоєнні роки повідомлень щодо іспансько-британських відносин не багато, хоча інформації щодо ситуації у самій Британії, зокрема щодо Ірландської проблеми, набагато більше, ніж щодо двосторонніх відносин між обома країнами. Та й ця інформація, що наявна, є фрагментарною та не дає чіткої картини двосторонніх відносин.

У Першій світовій війні Іспанія залишалася нейтральною країною, тому по її завершенню кардинальних змін в іспансько-британських відносинах не трапилося. Обидві держави підтримували досить тісні дипломатичні, культурні, економічні та торгівельні зв’язки. Ще наприкінці війни 1 липня 1917 р. іспанський посол Меррідель-Валь вирушив з дипломатичною місією до Лондона для вирішення важливих питань щодо подальшої співпраці між двома країнами 6.

Щодо політичної співпраці, то за повідомленням преси, 28 вересня 1919 р. було ратифіковано договір між Іспанією та Великою Британією щодо видачі злочинців, які втекли з Іспанії та окремих, чітко визначених штатів півострова. Головою відомства, що мав слідкувати за виконанням умов угоди, і секретарем того ж відомства було призначено іспанця Альваро Гомеса7.

Розвивалися й торгівельні відносини. 23 березня 1922 року у звіті Генеральної асамблеї Торгової палати Іспанії у Лондоні зазначається: «Іспанські торгові угоди повинні гарантувати нашій країні такі умови, що мають важливе значення для нашого виробництва і збільшують багатство нашого сільського господарства експортом продовольчих товарів. Цей результат буде неможливо досягти, якщо ми не підемо на поступки країнам, з якими ми маємо комерційні відносини. Позиція Торгової палати полягає в тому, що при переговорах про торгові угоди обмеження їх тривалості повинно бути суттєвим моментом. Період не повинен бути занадто довгим або занадто коротким, щоб досягти плодів переговорів. 3 огляду на умови кожної нації, десять років можна вважати достатнім періодом для домовленостей, про які зараз ведуться переговори. Проекти контрактів, подані іспанською палатою, грунтуються на прагненні захистити іспанську промисловість...»8.

Ми вважаємо, що такі торгівельні умови, які були запропоновані іспанською Торговою палатою були позитивно прийняті, зокрема британською стороною. Так, 1923 р. за повідомленням «Reuter» відбулися щорічні загальні збори Торгової палати Іспанії в Лондоні, головував на яких пан Меррі-дель-Валь. На засіданні також були присутні лорд Кюльсант, генеральний консул Конгосто, віце-консул Лекуану та президент Торгово-промислової палати Хосе Рура. Звіт за 1922 р. свідчив, що імпорт 3 Іспанії до Великої Британії збільшився до 23,16,632 песет, а експорт з Англії до Іспанії - до 14667 662. Пан Мерр-дель-Валь, зазначив у своєму виступі, що не має причин песимізму в даний час - Іспанія повинна дивитися в майбутнє із радістю. Іспанський експорт надзвичайно збільшився з 1920 р., і в даний час спостерігається великий рух імпорту британських товарів до Іспанії. Він наголосив, що Велика Британія $\epsilon$ найкращим другом Іспанії, з якою вона була пов'язаназ давніх часів9.

Однак, такий позитивний розвиток торгівельних іспано-британських відносин 3 часом погіршився. Газета «La Vanguardia» зазначає, що «1928 рік був одним із найскладніших для англо-іспанської торгівлі. Прогнозований перегляд митних зборів породив сумніви та побоювання, які, безумовно, не допомогли відносинам між Іспанією та Англією»10. Газета наголошує, що тривожні кампанії англійської преси завдали великої шкоди Іспанії і що туристичні агентства втратили тисячі фунтів протягом тижня ${ }^{11}$. Хоча, звичайно, британська преса просто висвітлила хвилювання в Барселоні і жорстке придушення суспільного невдоволення владою, проте саме висвіт-

\footnotetext{
${ }^{6}$ La Vanguardia, (1917, 24 junio), p. 9.

7 La Vanguardia, (1919, 28 septiembre), p. 14.

${ }^{8}$ Reuter, (1922, 23 marzo), p. 19

${ }_{9}$ Reuter, (1923, 22 marzo), p. 19.

${ }^{10}$ La Vanguardia, (1929, 26 de abril), p. 24.

${ }^{11}$ La Vanguardia, (1928, 15 de noviembre), p. 25.
} 
лення цих подій сприяли зменшенню потоку туристів, в тому числі і британських, до Іспанії, що зменшило притік до іспанського бюджету коштів від туризму.

У той же час, іспанська преса дає нам детальну інформацію про зустрічі, візити, церемонії вручення грамот послів. Так, наприклад, у липні 1926 р. король Іспанії та його оточення у супроводі маркізів Меррі-дель-Валь відвідали Оксфордський університет, де йому було присвоєно звання доктора «honois causa». Король виголосив таку промову: «Лорд-канцлер, пане віце-канцлер, пані та панове...ей великий центр британської науки, який носить ім'я Оксфорд, завоював, в ході блискучої історії в минулому і такою великою наукою в сьогоденні заслужив повагу і шанобливе ставлення у всьому цивілізованому світі. Крім того, це вперше у вашій історії, що іспанський суверен отримує науковий ступінь вашого великого університету та вступає до цієї зали. Оксфорд все-таки має старі зв'язки з Іспанією, адже цей університет пов'язаний з ім'ям королеви Катерини де Арагон (дружиною англійського короля Генріха VIII, в дівоцтві іспанська принцеса - прим. автора), королевою, кров якої протікає по моїх венах...»12. Звичайно, монархам були властиві високопарні промови, в той же час, їх проголошували не в багатьох випадках і не багатьом адресатам, що також свідчить про цінність відносин Іспанії і Британії по монаршій лінії.

Повідомляється також, про церемонію у 1928 р., на якій новий посол Англії, в Мадриді, сер Джордж Грахейм вручив королю свої вірчі грамоти. Увійшовши до тронної кімнати, посол, пройшовши кілька кроків, віддав ввірені йому грамоти королю, а король, в свою чергу, передав їх генералу Примо де Рівера як державному міністру13. Після того посол проголосив: «Я маю честь передати Вашій Величності грамоту короля, мого правителя. Суверен, відкликаючи мого попередника сера Горація Румбольда, вповноважив мене як свого надзвичайного посла у вашій державі. Король Англії попросив висловити Вам від його імені щиру дружбу та підтвердити його постійний інтерес до успіхів Вашої Величності, а також до Її Величності Матері-Королеви та іспанської королівської родини (Король Альфонсо XIII був одружений на британській принцесі Вікторії Евгенії Батенберг - прим. автора) ${ }^{14}$.

Надалі в повідомленні йдеться про факт нещодавнього призначення короля Іспанії Альфонса XIII маршалом армії Великої Британії. Зі слів посла нам стає відомо, що на це позитивно відреагувала громадська думка Великої Британії, а Британська армія оцінила надану їй честь, яку отримала, прийнявши такого головнокомандувача. I далі посол висловлює цінність відносин між Іспанією та Британією для Британського монарха, але втілюючи їх як свою думку: «Я вважаю себе особливо привілейованим, оскільки був призначений представляти Велику Британію в Іспанії, в той час коли престиж іспанської нації має високе міжнародне значення. [...] Буде моїм найсильнішим і незмінним прагненням підтримувати тісні відносини, які існують так давно між Іспанією та Британською імперією, я сподіваюся, що мій видатний попередник переслідував такі ж цілі що і я. Я починаю своє завдання з радістю, знаючи, що я завжди можу покластися на милосердну доброзичливість Вашої Величності, дружню допомогу видатного глави вашого уряду та співпрацю людей, відповідальних за різні відомства держави». Король не залишив такі слова без уваги і відповів наступним чином, підкреслюючи важливе становище Великої Британії на міжнародній арені та прихильність Іспанії: «Пане посол, я дуже радий отримувати з ваших рук одночасно грамоти нашого видатного попередника, листи, які передає Його Величність Король Великої Британії. Я дякую Вам, пане посол, за привітання вашого суверена і прошу вас передати Його Величності свідчення про мою постійну і особливу прихильність. Міжнародний вплив Великої Британії завжди використовуватиметься, як ви правильно зазначаєте, для співпраці у підтримці миру та забезпеченні добробуту людства...»15.

${ }^{12}$ La Vanguardia, (1926, o6 julio), p. 22.

${ }^{13}$ La Vanguardia, (1928, 7 de febrero), p. 28.

14 Ibid.

${ }_{15}$ La Vanguardia, (1928, 07 octubre), p. 28. 
На відміну від іспанської преси (яка висвітлювала всі аспекти діяльності Іспанії на міжнародній арені, в тому числі й іспансько-британські відносини), радянська преса свою увагу звернула на збройний конфлікт у Марокко, який тривав протягом 19211926 років та увійшов в історію як іспансько-французько-марокканська війна (відома також як Друга Марокканська, Третя Ріфська або просто Ріфська війна) - колоніальна війна Іспанії та (з 1925 р) Франції проти берберського емірату Ріф, створеного в результаті повстання в Північному Марокко ${ }^{16}$. Відмітимо, що питання Морокко і зокрема Танжеру в міжнародних відносинах на початку XX століття займало важливе місце, оскільки володіння Танжером (або безпосередній вплив на нього) відкривав шляхи до Африки. Не останнє місце Марокко і Танжер займали й у відносинах між Великою Британією та Іспанією, адже право на Гібралтар (яким з 1713 року володіє Британія) періодично викликало суперечки між обома країнами і часто ставало предметом перемовин між ними.

Так, за інформацією радянської газети «Пролетарская правда» дізнаємося, що Iспанія офіційно відхилила ратифікацію Танжерської угоди, мотивуючи відмову тим, що договір суперечить інтересам Іспанії. Між Англією та Іспанією відбуваються офіційні переговори з приводу обміну англійського Гібралтару на іспанську частину Марокко ${ }^{17}$. Відтак це свідчить про те, що Іспанія пропонує свої африканські колоніальні володіння в обмін на мис Гібралтар.

Звичайно, будь-які дії Британії близько узбережжя Франції чи Іспанії викликало невдоволення двох останніх. За свідченнями газети «Красный черноморец» стає відоме наступне: «Маневри британського флоту біля Балеарських островів, по лінії морського шляху - Франція-Алжир-Туніс, неприязно коментуються французької пресою. Занепокоєння урядових кіл Франції відображає газета «Еклер» яка пише: «В очах Франції, Італії та Іспанії пацифістська Англія намагається за допомогою своїх ескадр ще раз підтвердити гордовитий девіз: «Володарюй, Британія, морями»! Французька ескадра, зважаючи на англійські маневри у Середземному морі зосереджена в Тулоні»18. Так через ставлення французів до подій дізнаємося про заплутану ситуацію у Середземному морі.

Інша радянська газета, «Красное знамя» надала інформацію щодо таємної допомоги Великої Британії повстанцям у Марокко. «З Мадрида повідомили, що іспанське військове судно захопило англійський пароплав, який доставляв військове спорядження для повстанців у Марокко. Звичайно, через даний випадок, відносини між країнами стали напруженими 19.

В свою чергу, з Гібралтару повідомляли, що два винищувачі вийшли в Танжер 3 3000 солдатами, повернулися назад і готові в будь-який момент відправитися в Танжер. На думку радянської преси, Англія. мабуть, бажає скористатися труднощами Іспанії в Марокко і затвердити свій вплив у Танжері, на який претендує Франція²0.

У ситуації, що склалася, громадська думка в Радянському Союзі, була повністю на стороні Іспанії. Так, для прикладу, в газеті «Коммунист» вийшла стаття С. Яворського щодо подій у Марокко. Ї̈ важко назвати джерелом, але вона точно вийшла інформативною щодо того, як радянська влада бачила події на Півночі Африки. В цій статті зазначалося, що «...єиипетські заворушення тривають нібито через неприязнь туніських магометан до Франції. Хоча ненависть мешканців Тунісу до французьких завойовників не підлягає сумніву, тим не менш не з цієї причини уряд Eppio поспішає підкреслити увагу, з якою він стежить за подіями в Північній Африці. Він нічого не має проти зміцнення позицій Англії в Єгипті, але лише за однієї умови,

${ }^{16}$ Guerra del Rif. Retrieved from http://www.ecured.cu/Guerra_del_Rif; Nogué, J. \& Villanova, J.L. (Eds.) (1999). España en Marruecos (1912-1956). Discursos geográficos e intervención territorial, 17 .

17 Пролетарская правда, (1924, 3 января), с. 2.

${ }_{18}$ Красный черноморец, (1924, 14 марта), с. 1.

19 Красное знамя, (1924, 16 марта), с. 1.

20 Луганская правда, (1924, 28 декабря), с. 1. 
щоб за дружній нейтралітет Англія сплатила їй не менш дружньою байдужістю до того, що Франція збирається зробити в іншій частині північної Африки, в Марокко. На даний час немає вже жодного сумніву в повному краху іспанської окупації північного Марокко. Таємна угода 1904 року між Францією та Іспанією про розділ «сфер впливу» в Марокко перетворилася після останньої світової війни в фактичний розподіл марокканської території між Францією та Іспанією» 21 . Далі у статті дається історична довідка щодо подій у Північно-Західній Африці та інтересів європейських країн, що перетинаються на цій території. Зокрема, автор зазначає, що «угода 1904 року, як і остаточне закріплення за Іспанією Середземного узбережжя Марокко відбулися за повного схвалення Англією. Англійський імперіалізм, який не мав можливості захопити північне Марокко, побоювався залишити його в руках могутньої Франції. Він вважав за краще, щоб територія, що примикає до Середземного моря, перейшла до рук слабкої Іспанії. Іспанія є давнішним васалом Англії і знаходиться під іï фінансовим і політичним впливом. До тих пір, поки гавані Сеута і Лараш належать Іспанії, англійському імперіалізму нічого побоюватися за безпеку Гібралтарської протоки і найкоротших шляхів до Індії. Само собою зрозуміло, що Франція примирилася з участю Іспанії в розподілі багатої мароккської території».

Фундаментальним є пояснення того, що відбувається в Іспанському Марокко, i чому там чиниться набагато більше заворушень, ніж у Французькому Марокко. Відмічено, що, по-перше, Іспанська частина Марокко $\epsilon$ ареною безперервних повстань, а населення цієї території $є$ більш войовничим. По-друге, французьке управління в колоніях м’якіше іспанського, навіть кількість іспанської армії є більшою за французьку в Марокко. По-третє, наголошено на чудовому озброєнні ріфських племен, яке дозволяє їм громити іспанську армію, і на тому, що, можливо, воно має французьке походження. Зазначено, що Франція має бажання руками марокканських повстанців витіснити Іспанію з метою отримання доступу до Середземноморського узбережжя Марокко. Четвертий аспект є важливим, в ньому наголошується на значенні Англії у цьому питанні: «Єдине, що заважає планам французьких завойовників - це Англія. Для французького уряду абсолютно ясно, що без угоди з Англією Франції не вдасться стати твердою ногою в іспанській частині Марокко. ...Заради отримання в свої руки іспанської зони Франція охоче погодиться поступитися Іспанії або Англії деякими приморськими містами Марокко на Середземному морі, зокрема Сеутою. Приєднання всіх інших територій, що входять до сфери «іспанського впливу», завершить об’єднання Марокко під французьким «протекторатом». За цю ціну Франція без коливань дасть свою згоду на розправу з Єгиптом i, звичайно, забуде про свої скарги на небезпеку, нібито загрозливу для французького панування в Тунісі...»22.

Отож, помічаємо опосередковану допомогу Великої Британії в питанні Марокко, коли перша не дає змогу Франції збільшии свою присутність у регіоні за рахунок іспанської частини. Але пригадаємо, що за повідомленнями радянських газет «Красный черноморец» № 61 від 14 березня 1924 року та «Красное знамя» № 50 від 16 березня 1924 року Британія сприяла повстанню в Іспанському Марокко через постачання зброї, тому позиція Великої Британії полягала в недопущенні посилення позицій жодної з країн, ані Франції, ані Іспанії. Британія дотримувалася своїх інтересів, тому Іспанія не могла на неї покластися на 100\% в питаннях щодо Марокко.

Газета «Вечернее радио» 20 травня 1925 року повідомила, що «наступ марокканських повстанців по всьому фронту французьких військ триває. Положення французької армії надзвичайно важке. Низка паризьких газет, у тому числі, органи соціалістів і радикал-соціалістів, у сьогоднішніх статях дивляться досить скептично. Французькі урядові кола прагнуть організації загального наступу Франції, Іспанії й Англії проти марокканських повстанців, при чому французькі й іспанські війська мають діяти на суші, координуючи свої дії з операціями англійського флоту на узбереж-

${ }^{21}$ Коммунист, (1924, 30 ноября), с. 1.

22 Ibid. 
жі»23. Відтак при успішному наступі ріфських племен на французькі чи іспанські війська всі три країни - Іспанія, Франція і Британія - поєднували свої сили для подолання супротиву марокканців.

Важливим для Іспанії та Великої Британії було і питання Гібралтару. Раніше ми згадували, що, хоча проблема Гібралтару є каменем спотикання в англійськоіспанських відносинах, однак в іспанській пресі це мало висвітлювалось. Наприклад, у 1929 р. в «La Vanguardia» з'являється така інформація: «Повідомляємо, що між Іспанією та Великою Британією відбулися переговори про переведення Гібралтару під контроль Іспанії в обмін на Сеуту. Серед іншого, було затверджено з'єднання телефонної лінії між Ла-Лінеєю та Гібралтаром²4.

I нарешті, щодо відносин між Іспанією та Великою Британією у галузі культури. Так, обидві держави підтримували досить тісні дипломатичні, культурні, економічні та торгівельні зв’язки. «La Vanguardia» від 23 липня 1929 року повідомляє, що представники Великої Британії взяли участь у міжнародній виставці в Мадриді. Відкриття англійської секції відбулося урочисто за допомогою багатьох державних установ та вищих посадових осіб: британської торгової палати в Іспанії та ії президента Артуро Вітті; посла Англії в Мадриді Грехема, Кендалла Парка, організатора секції; полковника Коле, делегата британського уряду, пана Адамса, комерційного секретаря посольства в Мадриді; всіх органів Барселони; директора виставки; членів британського комітету25. Організатори виставки зазначили, що участь англійців у виставці сприяє посиленню доброї дружби та комерційних відносин між Англією та Іспанією.

Результати дослідження. Таким чином, систематизуючи та узагальнюючи інформацію на сучасному етапі розслідування, ми можемо зробити наступні висновки:

1) Іспаномовні газети детально висвітлювали міжнародне становище та зовнішню політику Іспанії в 20-30-ті pp. XX ст. Велику увагу вони приділяли саме відносинам 3 Великою Британією, яка була однією з основних дипломатичних, комерційних, культурних парнерів. Зокрема, фрагментарний характер висвітлення відносин помічаємо у газеті «La Vanguardia», яка повідомляла про відносини у сфері торгівлі, дипломатичного етикету та культури, окремих політичних питань, що безумовно були найважливішими питаннями на той час у відносинах між державами. Однак на сторінках зазначеної газети зустрічається недостатньо інформації про Гібралтар, яке було важливим питанням у дипломатії обох країн того часу.

«Reuter», повідомлення якого часто друкувалися у «La Vanguardia» і яке було одним з найбільших у світі міжнародних агентств новин і фінансової інформації, активно висвітлював економічні, торгівельні та комерційні відносини між Іспанією та Великою Британію. Також газета активно надавала інформацію про дипломатичні візити, аудієнції послів, цитувала промови монархів та політиків.

2) Радянська преса, висвітлюючи іспансько-британські відносини, більше уваги приділяла війні в Марокко, і зовсім оминала інші сфери зовнішньої політики між Іспанією та Великою Британією, тому інформація була недостатньо повною. Проте, відносини між Іспанією та Британією в напрямку Марокко подавалися у розрізі багатофакторності, оскільки вказувалося, як на англійську політику в Марокко впливає бажання послабити позицію Франції на цій території.

3) Якщо «La Vanguardia» висвітлюючи іспансько-британські відносини, прагнула подавати їх у двосторонньому форматі та суто факти, то на сторінках радянських газет зустрічаємо аналіз, в якому висвітлюється розстановка сил у Північній Африці й позиція Британії в цьому регіоні, через що ця інформація втрачає свою об'єктивність, тому інформацію з цього джерела варто використовувати з обережністю.

Однак, ця невелика кількість інформації доводить, що відносини між двома країнами були розвиненими в економічній сфері, але складними та суперечливими у по-

23 Вечернее радио (1925, 20 мая), с. 2.

24 La Vanguardia, (1929, 2 de Agosto), p. 16.

25 La Vanguardia, (1929, 23 de junio), p. 10. 
літичному напрямі, що не завадило двом монархічним державам налагоджено співпрацювати.

\section{REFERENCES}

Guerra del Rif. Retrieved from http://www.ecured.cu/Guerra_del_Rif [in Spanish]

Khudolei, K.K. (2017). Evoliutsiia idei mirovoi revoliutsii v politike Sovetskogo Soiuza (epokha Kominterna i sotsializma v odnoi strane). [The Evolution of the Idea of World Revolution in Soviet Politics (The Epoch of the Comintern and Socialism in One Country)]. Vestnik SPbGU. Politologiia. Mezhdunarodnye otnosheniia, 10 (2), 145-165. DOI: 10.21638/11701/spbu06.2017.205 [in Russian]

Nogué, J. \& Villanova, J.L. (Eds.) (1999). España en Marruecos (1912-1956). Discursos geográficos e intervención territorial. Lleida: Editorial Milenio. [in Spanish]

Sergeev, E.Yu. (2015). Ultimatum Kerzona Sovetskoi Rossii 1923 g.: novaia interpretatsiia [Curzon's Ultimatum to the Soviet Russia in 1923: new interpretation]. Vestnik RGGU. Seriia: Politologiia. Istoriia. Mezhdunarodnye otnosheniia, 97-105. [in Russian]

Serrano, C.S. (2018) Alfonso XIII. Real Academia de la Historia. Retrieved from http://dbe.rah.es/biografias/6415/alfonso-xiii [in Spanish]

Volosiuk, O.V., Mednikov, I.Yu. \& Pozharskaia, S.P. (2013) Istoriia vneshnei politiki Ispanii [History of Foreign Policy of Spain]. Moskva: Mezhdunarodnye otnosheniia [in Russian]

Anastasiia Khmel,

Petro Mohyla Black Sea National University, Mykolaiv, Ukraine ORCID https://orcid.org/oOOO-OOO2-4881-7859

Lidiia Bilichenko,

Petro Mohyla Black Sea National University, Mykolaiv, Ukraine ORCID: https://orcid.org/oOoO-OOO1-5547-9248

\section{Development of Spain-Britain relations after the First World War (based on Spanish and Soviet newspapers)}

The issue of the development of Spanish-British relations after the First World War has been poorly studied by both foreign and domestic scholars. Therefore, even at the present stage in the writings of researchers there is a view that in the interwar period, the relations between the two countries almost did not develop. In view of this, the authors have set themselves the goal, on the basis of the Spanish and Soviet periodicals of that period, which was one of the main sources of information, to analyze Spanish-British relations after the First World War. The study found that relations between Spain and the United Kingdom were complex and strained during the 1920 s and 1930s. On the one hand, this was facilitated by the civil war and the armed conflict in Morocco (1921-1926), during which relations between the two colonial countries deteriorated significantly. Gibraltar has also remained unresolved, although some agreement has been reached on this issue. In particular, it was decided to connect the telephone line between La Linea and Gibraltar. On the other hand, despite some misunderstandings, both countries maintained close diplomatic, cultural, economic and trade ties. The press of that period contains information about diplomatic visits, audiences and more. For example, in July 1926 the King of Spain and his entourage, accompanied by the Spanish ambassador to the United Kingdom, Merry del Val, visited the University of Oxford, where the King was awarded the honorary title of Doctor. This amicable attitude of the Spanish and British monarchs to each other was also caused by the fact that the King of Spain Alfonso XIII was married to Princess Eugenia Battenberg Victoria, who was the granddaughter of the Queen of Great Britain Victoria and was brought by the cousin sister of the Acting British ruler of the Royal Majesty. The relations between the two countries were complex and contradictory, but this did not prevent the two monarchical states from cooperating.

Key words: Spain, United Kingdom, Soviet Union, relations, First World War, press 